\title{
Effect of increasing levels of apparent metabolizable energy on laying hens in barn system
}

\author{
Hwan Ku Kang', Seong Bok Park', Jin Joo Jeon ${ }^{1}$, Hyun Soo Kim', Ki Tae Park', \\ Sang Ho Kim', Eui Chul Hong', and Chan Ho Kim,*
}

\author{
* Corresponding Author: Chan Ho Kim \\ Tel: +82-33-330-9556, Fax: +82-33-330-9549, \\ E-mail: kch8059@korea.kr \\ 1 Poultry Research Institute, Rural Development \\ Administration National Institute of Animal Science, \\ Pyeongchang 25342, Korea \\ ORCID \\ Hwan Ku Kang \\ https://orcid.org/0000-0002-4286-3141 \\ Seong Bok Park \\ https://orcid.org/0000-0003-2557-6084 \\ Jin Joo Jeon \\ https://orcid.org/0000-0001-7585-4746 \\ Hyun Soo Kim \\ https://orcid.org/0000-0001-8887-1318 \\ Ki Tae Park \\ https://orcid.org/0000-0002-0931-3519 \\ Sang Ho Kim \\ https://orcid.org/0000-0002-7203-8863 \\ Eui Chul Hong \\ https://orcid.org/0000-0003-1982-2023 \\ Chan Ho Kim \\ https://orcid.org/0000-0003-2121-5249
}

Submitted Nov 20, 2017; Revised Dec 18, 2017; Accepted Mar 30, 2018
Objective: This experiment was to investigate the effect of increasing levels of apparent metabolizable energy $\left(\mathrm{AME}_{\mathrm{n}}\right)$ on the laying performance, egg quality, blood parameters, blood biochemistry, intestinal morphology, and apparent total tract digestibility (ATTD) of energy and nutrients in diets fed to laying hens.

Methods: A total of three-hundred twenty 33-week-old Hy-Line Brown laying hens (Gallus domesticus) were evenly assigned to four experimental diets of 2,750, 2,850, 2,950, and 3,050 $\mathrm{kcal} \mathrm{AME} / \mathrm{kg}$ in pens with floors covered with deep litter of rice hulls. There were four replicates of each treatment, each consisting of 20 birds in a pen.

Results: $\mathrm{AME}_{\mathrm{n}}$ intake was increased (linear, $\mathrm{p}<0.05$ ) with inclusion level of $\mathrm{AME}_{\mathrm{n}}$ in diets increased. Feed intake and feed conversion ratio were improved (linear, $\mathrm{p}<0.01$ ), but hen-day egg production tended to be increased with an increasing level of $\mathrm{AME}_{\mathrm{n}}$ in diets. During the experiment, leukocyte concentration and blood biochemistry (total cholesterol, triglyceride, glucose, total protein, calcium, asparate aminotransferase, and alanine transferase were not influenced by increasing level of $\mathrm{AME}_{\mathrm{n}}$ in diets. Gross energy and ether extract were increased (linear, $\mathrm{p}<0.01$ ) as the inclusion level of $\mathrm{AME}_{\mathrm{n}}$ in diets increased.

Conclusion: Laying hens fed high $\mathrm{AME}_{\mathrm{n}}$ diet (i.e., $3,050 \mathrm{kcal} / \mathrm{kg}$ in the current experiment) tended to overconsume energy with a positive effect on feed intake, feed conversion ratio, nutrient digestibility, and intestinal morphology but not on egg production and egg mass.

Keywords: Feed Intake; Intestinal Morphology; Laying Hen Performance; Metabolizable Energy; Nutrient Digestibility

\section{INTRODUCTION}

Dietary energy density, an important nutrient in layer diets, is typically supplied by cereal and protein source and supplemental fat. Dietary energy level can significantly affect the cost of production, because increasing energy levels by the addition of fat can significantly decrease feed intake, increase egg weight, and improve feed conversion [1-3]. Increasing dietary energy by addition of poultry oil has been shown to significantly affect percentage of egg components [4]. There is also a wide range of dietary energy levels (2,684 to 2,992 $\mathrm{kcal}$ of metabolizable energy [ME]/kg) currently being used by the egg industry. However, there is limited information concerning the ideal dietary energy level required for optimal laying performance [4]. When the AME content of the diet is increased it could improve nutrient utilization and egg weight [1]. Grobas et al [5] reported that increase in the apparent metabolizable energy $\left(\mathrm{AME}_{\mathrm{n}}\right)$ content of the diet from 2,680 to 2,810 kcal/kg decreased feed intake by $5.0 \%$ but that egg production and egg mass were not affected. Similarly, Peguri and Coon [6] reported a 5\% decrease in feed intake and similar egg production when the 
AME of the diet was increased from 2,700 to 2,910 kcal/kg. Junqueira et al [7] did not detect any difference in Haugh units or egg shell quality in brown egg laying hens fed diets varying in AME content from 2,850 to 3,050 kcal/kg. The authors have not found any published information on the effects of energy concentration of the diet on serum cotricosterone and intestinal morphology.

The hypothesis of the current experiment was that an increase in $\mathrm{AME}_{\mathrm{n}}$ concentration of the diet could improve energy intake and productive performance of the laying hens. To the best of our knowledge, limited research has been published on the increasing levels of $\mathrm{AME}_{\mathrm{n}}$ on laying performance, leukocyte concentration, blood biochemistry, intestinal morphology, and apparent total tract digestibility (ATTD) of energy and nutrients in diets fed to laying hens in barn system.

\section{MATERIALS AND METHODS}

The protocol for this experiment was reviewed and approved by the Institutional Animal Care and Welfare Committee of the National Institute of Animal Science, Rural Development Administration, Republic of Korea.

\section{Birds and experimental design}

A total of three-hundred twenty 33-week-old Hy-Line Brown laying hens (Gallus domesticus) were evenly assigned to four experimental diets of 2,750, 2,850, 2,950, and 3,050 $\mathrm{kcal} \mathrm{AME} / \mathrm{kg}$ in pens with floors covered with deep litter of rice hulls. There were four replicates of each treatment, each consisting of 20 birds in a pen. A commercial type basal diet was formulated to meet or exceed the nutrient recommendations of the $\mathrm{Na}$ tional Research Council [8] for layers (Table 1). The diets were analysed in duplicate to determine the crude protein $(\mathrm{CP})$, crude ash, ether extract, and the gross energy (GE) content. Nitrogen for $\mathrm{CP}$ analysis was measured using a nitrogen analyzer (NS-2000, Leco Corp., St. Joseph, MI, USA). Dry matter was determined according to the method of Association of Official Analytical Chemists [9], and GE was determined using a Parr adiabatic oxygen bomb calorimeter (Parr Instrument Co., Moline, IL, USA). The diet samples were subjected to analyses of ether extract [9]. The diets were offered daily and were stored at $4^{\circ} \mathrm{C}$ during the course of the trial. During the 10-week experimental period, hens were provided with feed and water ad libitum and were exposed to a $16 \mathrm{~h}: 8 \mathrm{~h}$ (light:dark) schedule. The temperature and humidity of the laying house was maintained at $20^{\circ} \mathrm{C} \pm 3^{\circ} \mathrm{C}$ and $65 \%$ to $70 \%$ respectively.

\section{Laying performance}

Hen-day egg production rate, floor eggs, broken egg production rate and egg weight were recorded daily, whereas feed intake and the feed conversion ratio were recorded weekly. Egg mass was calculated as per Hayat et al [10].
Table 1. Composition and nutrient content of experimental diet

\begin{tabular}{|c|c|c|c|c|}
\hline \multirow{2}{*}{ Ingredients (g/kg) } & \multicolumn{4}{|c|}{ Dietary $\mathrm{AME}_{\mathrm{n}}$ concentration $(\mathrm{kcal} / \mathrm{kg})$} \\
\hline & 3,050 & 2,950 & 2,850 & 2,750 \\
\hline Corn & 529.5 & 545.2 & 570.7 & 596.1 \\
\hline Wheat & 50.0 & 60.0 & 60.0 & 60.0 \\
\hline Soybean meal & 248.5 & 242.7 & 238.0 & 233.5 \\
\hline Soybean oil & 62.5 & 42.6 & 21.8 & 1.0 \\
\hline Mono-dicalcium phosphate & 10.8 & 10.8 & 10.8 & 10.6 \\
\hline Limestone & 92.7 & 92.7 & 92.7 & 92.8 \\
\hline Sodium chloride & 2.5 & 2.5 & 2.5 & 2.5 \\
\hline D,L-methionine-99\% & 1.5 & 1.0 & 1.0 & 1.0 \\
\hline Vitamin premix ${ }^{1)}$ & 1.0 & 1.0 & 1.0 & 1.0 \\
\hline Mineral premix ${ }^{2)}$ & 1.0 & 1.0 & 1.0 & 1.0 \\
\hline Total & $1,000.0$ & $1,000.0$ & $1,000.0$ & $1,000.0$ \\
\hline \multicolumn{5}{|l|}{ Calculated composition $^{3)}$} \\
\hline $\mathrm{AME}_{\mathrm{n}}(\mathrm{kcal} / \mathrm{kg})$ & $3,050.0$ & $2,950.0$ & $2,850.0$ & $2,750.0$ \\
\hline Crude protein (g/kg) & 175.0 & 175.0 & 175.0 & 175.0 \\
\hline Calcium $(\mathrm{g} / \mathrm{kg})$ & 38.0 & 38.0 & 38.0 & 38.0 \\
\hline Available P (g/kg) & 32.0 & 32.0 & 32.0 & 32.0 \\
\hline Lysine $(\mathrm{g} / \mathrm{kg})$ & 71.0 & 71.0 & 71.0 & 71.0 \\
\hline Methionine+cyseine (g/kg) & 88.0 & 88.0 & 88.0 & 88.0 \\
\hline \multicolumn{5}{|l|}{ Analyzed composition ${ }^{4)}$} \\
\hline Gross energy (kcal/kg) & $3,955.2$ & $3,855.2$ & $3,734.8$ & $3,630.5$ \\
\hline Calcium $(\mathrm{g} / \mathrm{kg})$ & 46.3 & 45.7 & 46.0 & 45.2 \\
\hline $\mathrm{DM}(\mathrm{g} / \mathrm{kg})$ & 903.4 & 904.6 & 904.1 & 901.9 \\
\hline Crude protein $(\mathrm{g} / \mathrm{kg})$ & 184.4 & 184.6 & 184.8 & 184.7 \\
\hline Crude ash (g/kg) & 154.6 & 154.4 & 158.4 & 149.7 \\
\hline Ether extract $(\mathrm{g} / \mathrm{kg})$ & 55.6 & 49.9 & 43.2 & 27.0 \\
\hline
\end{tabular}

$\mathrm{AME}_{n}$, apparent nitrogen corrected metabolizable energy; DM, dry matter.

1) Provided per kilogram of the complete diet: vitamin $A$ (vitamin $A$ acetate), 12,500 IU; vitamin $D_{3}, 2,500 \mathrm{IU}$; vitamin $\mathrm{E}$ (DL- $\alpha$-tocopheryl acetate), $20 \mathrm{IU}$; vitamin $\mathrm{K}_{3}, 2$ mg; vitamin $\mathrm{B}_{1}, 2 \mathrm{mg}$; vitamin $\mathrm{B}_{2}, 5 \mathrm{mg}$; vitamin $\mathrm{B}_{6}, 3 \mathrm{mg}$; vitamin $\mathrm{B}_{12}, 18$

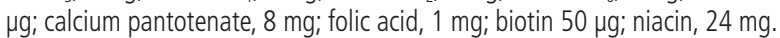

2) Provided per kilogram of the complete diet: $\mathrm{Fe}\left(\mathrm{FeSO}_{4} \cdot 7 \mathrm{H}_{2} \mathrm{O}\right), 40 \mathrm{mg}$; $\mathrm{Cu}(\mathrm{Cu}-$ $\left.\mathrm{SO}_{4} \cdot \mathrm{H}_{2} \mathrm{O}\right), 8 \mathrm{mg} ; \mathrm{Zn}\left(\mathrm{ZnSO}_{4} \cdot \mathrm{H}_{2} \mathrm{O}\right), 60 \mathrm{mg} ; \mathrm{Mn}\left(\mathrm{MnSO}_{4} \cdot \mathrm{H}_{2} \mathrm{O}\right) 90 \mathrm{mg} ; \mathrm{Mg}(\mathrm{MgO})$ as $1,500 \mathrm{mg}$.

${ }^{3)}$ Nutrient contents in all diet were calculated.

${ }^{4)}$ Analyzed in triplicated.

Egg mass

$=$ weekly number of eggs in a replicate $\times$ average egg weight

\section{Determination of egg quality parameters}

Ten eggs per replicate were randomly collected at the end of the each week. Eggshell strength, eggshell thickness, egg yolk color, and Haugh units (HU) were measured. Eggshell strength was measured by the Texture Systems Compression Test Cell (model T2100C, Food Technology Co., Ltd., Rockville, MD, USA) and expressed as units of compression force exposed to units of eggshell surface area $\left(\mathrm{kg} / \mathrm{cm}^{2}\right)$. Eggshell thickness is defined as the mean value of measurements at 3 different locations on the egg (air cell, equator, and sharp end) and was measured with a dial pipe gauge (model 7360, Mitutoyo Co. Ltd., Kawasaki, Japan) and calculated using the following formula [11]: 
Eggshell thickness

$=($ sharp point thickness + equator point thickness + air cell thickness)/3

Egg yolk colour was evaluated by the Roche Yolk Color Fan (Hoffman-La Roche Ltd., Basel, Switzerland; 15 = dark orange; $1=$ light pale). Haugh unit values were calculated using a micrometer (model S-8400, Ames, Walthman, MA, USA) with the following formula described by Eisen et al [12]:

$\mathrm{HU}=100 \log \left(\mathrm{H}-1.7 \mathrm{~W}^{0.37}+7.6\right)$,

Where $\mathrm{W}$ is egg weight, and $\mathrm{H}$ is albumen height.

\section{Hematological analysis}

At the end of the 10-week feeding trial, 2 birds/replicate (i.e., 8 birds per treatment) with a body weight near the mean were selected to be euthanized by cervical dislocation. Immediately after death, a $5 \mathrm{~mL}$ blood sample was collected from the jugular vein of each bird using ethylenediaminetetraacetic acid (EDTA)-treated and non-EDTA treated vacutainer tubes (Becton Dicknson, Franklin Lakes, NJ, USA). The whole blood samples were kept on ice and used immediately for hematological analysis. Leukocytes (white blood cells, heterophils, lymphocytes, monocytes, eosinophils, and basophils) were analyzed using the Hemavet Multi-species Hematology System (Drew Scientific Inc., Oxford, CT, USA). The H/L ratios were determined by dividing the number of heterophils by the number of lymphocytes.

\section{Blood biochemistry}

Serum samples were obtained by centrifuging the samples for $20 \mathrm{~min}$ at $25,000 \times \mathrm{g}$ and $4^{\circ} \mathrm{C}$ and were stored at $-15^{\circ} \mathrm{C}$. Total cholesterol, triglyceride, asparate aminotransferase (AST), alanine transferase (ALT), and calcium in the serum were quantified using an ADVIA 1650 Chemistry System (Bayer Diagnostic, Puteaux, France).

\section{Nutrient digestibility}

Birds were fed the experimental diets for $8 \mathrm{~d}$ with a 5 -d adaptation period to the diet and following 3-d excreta collection period. The marker to marker method was used to ensure total collection of excreta voided from the birds [13]. Chromic oxide $(0.3 \%)$ and ferric oxide $(0.3 \%)$ were added to the diet at the start of collection period and at the conclusion of the collection period, respectively. Excreta collection was started when chromic oxide was appeared in excreta, and the collection was finished when ferric oxide was appeared in excreta. Full caution was paid to prevent disturbing the birds whenever the feces were monitored. Feed intake was recorded and excreta were collected on a daily basis, and stored at $-4^{\circ} \mathrm{C}$ be for analysis. Excreta sample were dried in a force-air oven at $60^{\circ} \mathrm{C}$ for $72 \mathrm{~h}$ and finely ground for the subsequent analysis. Diets and excreta samples were analyzed for GE using bomb calorimeter (Parr Instrument, USA). The diets and excreta samples were analyzed for dry matter (Method 934.01), CP (Method 990.93), ether extract (Method 920.39), crude ash (Method 942.05) using standard procedures of Association of Official Analytical Chemists [9]. The ATTD of GE and nutrients in the diet was calculated as: 100 - (total GE or nutrient excretion/total GE or nutrient intake $) \times 100[14,15]$.

\section{Intestinal morphology measurements}

Morphometric analysis of the ileum (from Meckel's diverticulum to the ileo-caeco-colic junction) was evaluated according to Giannenas et al [16]. One-centimetre-long segments were taken from the centre of each part and fixed in $10 \%$ buffered formalin for morphometrical assays under light microscopy. Formalin-fixed intestinal tissues were processed, embedded in paraffin wax, sectioned at $3 \mu \mathrm{m}$ and stained the haematoxylin-eosin method. Histological sections were examined with a Nikon phase contrast microscope coupled with a Microcomp integrated digital imaging analysis system (Nikon Eclipse 80i; Nikon, Tokyo, Japan). Images were viewed using a $4 \times$ Eplan objective $(40 \times)$ to measure morphometric parameters of intestinal architecture. For this purpose, three favourably orientated sections cut perpendicularly from villus enterocytes to the muscularis mucosae were selected from each animal and measurements were carried as follows: villus height was estimated by measuring the vertical distance from the villus tip to villus-crypt junction level for 10 villi per section; crypt depth (the vertical distance from the villus-crypt junction to the lower limit of the crypt) was estimated for 10 corresponding crypts per section.

\section{Statistical analysis}

All data were analyzed by analysis of variance according to completely randomized design using the Proc MIXED procedure of SAS [17]. Outlier data were identified by the UNIVARIATE procedure of SAS, but no outliers were found. The experimental unit for all data was replicate. The LSMEANS procedure was used to calculate mean values. The orthogonal polynomial contrast test was performed to determine linear and quadratic effects of increasing $\mathrm{AME}_{\mathrm{n}}$ concentrations in diets.

\section{RESULTS AND DISCUSSION}

\section{Laying performance and egg quality}

$\mathrm{AME}_{\mathrm{n}}$ intake increased (linear, $\mathrm{p}<0.05$ ) as the inclusion level of $\mathrm{AME}_{\mathrm{n}}$ in diets increased. Feed intake decreased (linear, $\mathrm{p}<$ 0.01 ) as the inclusion level of $\mathrm{AME}_{\mathrm{n}}$ in diets increased. Increasing inclusion level of $\mathrm{AME}_{\mathrm{n}}$ in diets tended to improve hen-day egg production. Hen-day egg production of the 2,850, 
2950 , and $3,050 \mathrm{kcal} / \mathrm{kg}$ treatments compared to the 2,750 $\mathrm{kcal} / \mathrm{kg}$ treatment trended toward a non-significant increase of $1.09 \%, 2.54 \%$, and $3.51 \%$, respectively. Feed conversion ratio was improved (linear, $\mathrm{p}<0.05$ ) with inclusion level of $\mathrm{AME}_{\mathrm{n}}$ in diets increased. The feed conversion ratio of the other treatments improved by $1.59 \%, 4.76 \%$, and $7.16 \%$, respectively, compared to the $2,750 \mathrm{kcal} / \mathrm{kg}$ treatment (Table 2). Floor eggs, broken egg production, egg weight, and egg mass were not influenced by an increase in the inclusion level of $\mathrm{AME}_{\mathrm{n}}$ in diets (Table 3).

Hens eat to satisfy their energy requirements, and therefore, an increase in the energy content of the diet should decrease feed intake [18]. However, an increase in the current energy content of the diet from 2,750 to $3,050 \mathrm{kcal}$ of $\mathrm{AME}_{\mathrm{n}} / \mathrm{kg}$ (an $11 \%$ increase) resulted in a decreased feed intake of $4.7 \%$, resulting in a net increase in energy intake of $5.8 \%$. Bouvarel et al [19] reviewed experiments conducted in laying hens during the last $20 \mathrm{yr}$ and reported that as an average, a 10\% increase in $\mathrm{AME}_{\mathrm{n}}$ content of the diet resulted in a reduction in feed intake of only $5.5 \%$, in agreement with the results of the current experiment. An increase in energy content of the diet is generally attained by increasing the amount of fat and supplemental fat results often in higher energy intake, probably because of less dust formation and improved palatability of the diet $[19,20]$. Harms et al [2] reported in Brown hens and Single Comb White Leghorns (SCWL) fed diets varying in $\mathrm{AME}_{\mathrm{n}}$ from 2,500 to $3,100 \mathrm{kcal} / \mathrm{kg}$, there was no significant difference in hen-day egg production with changes in the energy content of the diet. These data support the hypothesis that an excess in energy intake caused by changes in diet composition results primarily in increases in body weight gain rather than in further increases in egg mass production. Egg weight was not affected by energy concentration of the diet, consistent with data of Grobas et al [1] and Bouvarel et al [19]. Bouvarel et al [19] analyzed data from 11 experiments conducted for the last 20 years and reported that egg weight increased $0.96 \mathrm{~g}$ per each $10 \mathrm{kcal}$ of extra energy intake per day. The reasons for the discrepancies in relation to the effects of an increase in energy content of the diet on egg weight are not apparent but might depend on the fat and the linoleic acid content of the diet. When the energy concentration of the diet increase, there is usually an increase in both fat and linoleic acid content. Feed conversion ratio improved as the energy content of the diet increased, in agreement with most published reports $[1,4,5]$. Hens eat feed to satisfy their energy requirements, and therefore, high $\mathrm{AME}_{\mathrm{n}}$ diets results in improved feed conversion ratio. Moreover, supplemental fat has been shown to reduce rate of feed passage, facilitating the contact between digesta and enzymes and improving digestibility and utilization of other nutrients such as the lipid and carbohydrate fractions of the diet. The results suggest that modern brown-egg-laying hens might not regulate accurately feed intake according to energy requirements when very high or low energy diets are used. Hens fed high $\mathrm{AME}_{\mathrm{n}}$ diet (i.e., 3,050 kcal/kg in the cur-

Table 2. Influence of the $\mathrm{AME}_{n}$ of the diet of the laying hens on productive performance ${ }^{1)}$

\begin{tabular}{|c|c|c|c|c|c|c|c|}
\hline \multirow{2}{*}{ Item } & \multicolumn{4}{|c|}{ Dietary $\mathrm{AME}_{\mathrm{n}}$ concentration $(\mathrm{kcal} / \mathrm{kg})$} & \multirow{2}{*}{ SEM } & \multicolumn{2}{|c|}{$p$-value } \\
\hline & 2,750 & 2,850 & 2,950 & 3,050 & & Linear & Quadratic \\
\hline Hen-day egg production (\%) & 82.7 & 83.6 & 84.8 & 85.6 & 1.67 & 0.10 & 0.28 \\
\hline Floor eggs (\%) & 2.74 & 2.77 & 2.11 & 1.93 & 0.75 & 0.35 & 0.28 \\
\hline Broken egg production rate (\%) & 1.76 & 1.94 & 1.90 & 1.16 & 0.48 & 0.22 & 0.36 \\
\hline Egg weight $(g)$ & 63.7 & 63.4 & 63.0 & 63.4 & 0.49 & 0.85 & 0.12 \\
\hline Feed intake (g/hen/d) & 133.1 & 131.1 & 127.9 & 126.9 & 1.24 & $<0.01$ & 0.41 \\
\hline Egg mass $(g / d)$ & 52.8 & 53.0 & 53.4 & 54.2 & 0.93 & 0.27 & 0.35 \\
\hline Feed conversion ratio $(\mathrm{kg} / \mathrm{kg})$ & 2.52 & 2.48 & 2.40 & 2.34 & 0.05 & 0.03 & 0.91 \\
\hline AME intake (kcal/hen/d) & 366.1 & 374.5 & 377.2 & 387.3 & 1.24 & 0.03 & 0.35 \\
\hline
\end{tabular}

$\mathrm{AME}_{n}$, apparent nitrogen corrected metabolizable energy; SEM, pooled error of mean.

1) Data are least squares means of 4 observations per treatment.

Table 3. Influence of the $A M E_{n}$ of the diet of the laying hens on egg quality ${ }^{1)}$

\begin{tabular}{|c|c|c|c|c|c|c|c|}
\hline \multirow{2}{*}{ Item } & \multicolumn{4}{|c|}{ Dietary $\mathrm{AME}_{\mathrm{n}}$ concentration $(\mathrm{kcal} / \mathrm{kg})$} & \multirow{2}{*}{ SEM } & \multicolumn{2}{|c|}{ p-value } \\
\hline & 2,750 & 2,850 & 2,950 & 3,050 & & Linear & Quadratic \\
\hline Eggshell strength $\left(\mathrm{kg} / \mathrm{cm}^{2}\right)$ & 3.96 & 3.97 & 3.98 & 4.06 & 0.29 & 0.39 & 0.35 \\
\hline Eggshell thickness ( $\mu \mathrm{m})$ & 374.2 & 365.6 & 369.8 & 376.8 & 4.59 & 0.18 & 0.28 \\
\hline Eggshell color & 12.1 & 12.2 & 12.2 & 12.1 & 0.59 & 0.79 & 0.53 \\
\hline Egg yolk color & 5.7 & 5.9 & 5.6 & 5.9 & 0.32 & 0.35 & 0.25 \\
\hline Haugh unit & 96.3 & 95.5 & 95.6 & 96.4 & 2.25 & 0.28 & 0.37 \\
\hline
\end{tabular}

$\mathrm{AME}_{n}$, apparent nitrogen corrected metabolizable energy; SEM, pooled error of mean.

1) Data are least squares means of 40 observations per treatment. 
rent experiment) tended to overconsume energy with a positive effect on feed intake and feed conversion ratio but not in egg production and egg mass. Energy concentration of the diet did not affect the percentage of dirty, broken or shell-less egg production rate throughout the laying period, consistent with data of Grobas et al [1].

\section{Hematological analysis and biochemical blood values}

During the experiment, leukocyte concentration and blood biochemistry (total cholesterol, triglyceride, glucose, total protein, calcium, AST, and ALT) were not influenced by increasing level of $\mathrm{AME}_{\mathrm{n}}$ in diets (Tables 4, 5). Blood parameters are good indicators of general health status, reflecting any physiologi- cal, nutritional and pathological changes occurring in the organism; however, it is important to establish appropriate reference values for these parameters [21]. Leukocyte count has also been used as a measure of immune function in birds [22]. Many factors, such as exposure to various microbes and chemicals, can cause changes in both granulocytic white blood cells [23]. The lack of adequate data on the role of increasing level of $\mathrm{AME}_{\mathrm{n}}$ in altering blood parameters in poultry requires further research.

\section{Apparent fecal digestibility of nutrients}

Nutrient digestibility from the present experiment is summarized in Table 6. Dry matter, CP, crude fiber, and crude ash

Table 4. Influence of the $A M E_{n}$ of the diet of the laying hens on blood parameters ${ }^{1)}$

\begin{tabular}{|c|c|c|c|c|c|c|c|}
\hline Item & \multicolumn{4}{|c|}{ Dietary $\mathrm{AME}_{\mathrm{n}}$ concentration (kcal/kg) } & SEM & \multicolumn{2}{|c|}{ p-value } \\
\hline \multicolumn{8}{|l|}{ Leukocytes } \\
\hline Heterophils $(\mathrm{K} / \mu \mathrm{L})$ & 8.64 & 8.50 & 8.38 & 8.50 & 0.58 & 0.71 & 0.52 \\
\hline Lymphocytes $(\mathrm{K} / \mu \mathrm{L})$ & 11.85 & 12.00 & 13.17 & 12.32 & 1.09 & 0.67 & 0.39 \\
\hline Eosinophils $(\mathrm{K} / \mu \mathrm{L})$ & 1.64 & 1.74 & 1.58 & 1.68 & 0.29 & 0.98 & 0.35 \\
\hline Basophils $(\mathrm{K} / \mu \mathrm{L})$ & 0.47 & 0.58 & 0.45 & 0.66 & 0.55 & 0.52 & 0.48 \\
\hline
\end{tabular}

$\mathrm{AME}_{n}$, apparent nitrogen corrected metabolizable energy; SEM, pooled error of mean.

${ }^{1)}$ Data are least squares means of 8 observations per treatment.

Table 5. Influence of the $\mathrm{AME}_{n}$ of the diet of the laying hens on blood biochemistry ${ }^{1)}$

\begin{tabular}{|c|c|c|c|c|c|c|c|}
\hline \multirow{2}{*}{ Item } & \multicolumn{4}{|c|}{ Dietary $\mathrm{AME}_{\mathrm{n}}$ concentration $(\mathrm{kcal} / \mathrm{kg})$} & \multirow{2}{*}{ SEM } & \multicolumn{2}{|c|}{$\mathrm{p}$-value } \\
\hline & 2,750 & 2,850 & 2,950 & 3,050 & & Linear & Quadratic \\
\hline Total cholesterol (mg/dL) & 125.5 & 127.7 & 128.2 & 129.3 & 12.03 & 0.25 & 0.38 \\
\hline Triglyceride (mg/dL) & $1,592.1$ & $1,519.4$ & $1,478.8$ & $1,508.8$ & 110.9 & 0.36 & 0.28 \\
\hline Glucose (mg/dL) & 191.5 & 204.7 & 197.0 & 200.6 & 7.30 & 0.45 & 0.39 \\
\hline Total protein (mg/dL) & 7.00 & 6.54 & 5.87 & 6.87 & 0.52 & 0.21 & 0.53 \\
\hline Calcium (mg/dL) & 29.6 & 28.6 & 26.1 & 27.1 & 1.02 & 0.52 & 0.66 \\
\hline AST (U/L) & 201.8 & 233.1 & 226.6 & 201.0 & 7.73 & 0.22 & 0.41 \\
\hline ALT (U/L) & 1.10 & 1.21 & 2.61 & 1.83 & 0.31 & 0.17 & 0.97 \\
\hline
\end{tabular}

$\mathrm{AME}_{n}$, apparent nitrogen corrected metabolizable energy; SEM, pooled error of mean; AST, asparate aminotransferase; ALT, alanine transferase.

1) Data are least squares means of 8 observations per treatment.

Table 6. Influence of the $\mathrm{AME}_{\mathrm{n}}$ of the diet of the laying hens on nutrient digestibility ${ }^{11}$

\begin{tabular}{|c|c|c|c|c|c|c|c|}
\hline \multirow{2}{*}{ Item } & \multicolumn{4}{|c|}{ Dietary $\mathrm{AME}_{\mathrm{n}}$ concentration (kcal/kg) } & \multirow{2}{*}{ SEM } & \multicolumn{2}{|c|}{ p-value } \\
\hline & 2,750 & 2,850 & 2,950 & 3,050 & & Linear & Quadratic \\
\hline Gross energy (g/kg) & 762.0 & 768.8 & 805.0 & 828.0 & 1.81 & 0.01 & 0.66 \\
\hline Dry matter $(\mathrm{g} / \mathrm{kg})$ & 733.4 & 703.6 & 693.0 & 699.4 & 2.45 & 0.32 & 0.47 \\
\hline Crude protein $(\mathrm{g} / \mathrm{kg})$ & 567.6 & 555.8 & 542.1 & 591.8 & 4.02 & 0.75 & 0.46 \\
\hline Ether extract $(\mathrm{g} / \mathrm{kg})$ & 760.0 & 824.5 & 868.3 & 931.8 & 1.53 & $<0.01$ & 0.97 \\
\hline Crude fiber $(\mathrm{g} / \mathrm{kg})$ & 802.9 & 804.2 & 810.4 & 819.2 & 2.79 & 0.67 & 0.89 \\
\hline Crude ash $(\mathrm{g} / \mathrm{kg})$ & 448.7 & 422.4 & 441.6 & 437.1 & 3.41 & 0.92 & 0.75 \\
\hline
\end{tabular}

$\mathrm{AME}_{n}$, apparent nitrogen corrected metabolizable energy; SEM, pooled error of mean.

${ }^{1)}$ Data are least squares means of 5 observations per treatment. 
Table 7. Influence of the $A M E_{n}$ of the diet of the laying hens on intestinal morphology ${ }^{11}$

\begin{tabular}{|c|c|c|c|c|c|c|c|}
\hline \multirow{2}{*}{ Item } & \multicolumn{4}{|c|}{ Dietary $\mathrm{AME}_{\mathrm{n}}$ concentration $(\mathrm{kcal} / \mathrm{kg}$ ) } & \multirow{2}{*}{ SEM } & \multicolumn{2}{|c|}{ p-value } \\
\hline & 2,750 & 2,850 & 2,950 & 3,050 & & Linear & Quadratic \\
\hline Villus height $(\mu \mathrm{m})$ & $1,026.3$ & $1,026.8$ & $1,161.3$ & $1,195.8$ & 35.99 & 0.01 & 0.65 \\
\hline Crypt depth $(\mu \mathrm{m})$ & 272.0 & 218.3 & 272.6 & 268.3 & 15.92 & 0.57 & 0.15 \\
\hline Villus height:crypth depth ratio & 3.92 & 4.71 & 4.37 & 4.50 & 0.34 & 0.38 & 0.35 \\
\hline
\end{tabular}

$\mathrm{AME}_{n}$, apparent nitrogen corrected metabolizable energy; SEM, pooled error of mean.

${ }^{1)}$ Data are least squares means of 5 observations per treatment.

were not influenced by increasing level of $\mathrm{AME}_{\mathrm{n}}$ in diets. However, GE and ether extract were increased (linear, $\mathrm{p}<0.01$ ) with inclusion level of $\mathrm{AME}_{\mathrm{n}}$ in diets increased (Table 6).

Mateos et al [24] reported that supplemental fat delays the intestinal transit time of the digesta, allowing a better contact between the components of the digesta and the endogenous enzymes present in the gastrointestinal tract, which in turn could improve nutrient utilization. The fat is almost completely absorbed in the small intestine of the bird, and therefore, GE ileal digestibility was expected to be higher for the supplemental fat containing diets [25].

\section{Intestinal morphology}

Intestinal morphology from the present experiment is summarized in Table 7. Villus height increased (linear, $\mathrm{p}<0.05$ ) as the inclusion level of $\mathrm{AME}_{\mathrm{n}}$ in diets increased. Crypth depth and villus height:crypth depth ratio was not influenced by increasing level of $\mathrm{AME}_{\mathrm{n}}$ in diets. Development of intestinal morphology could reflect the health status of the gastrointestinal tract of an animal. New epithelial cells are produced in the intestinal mucosal crypts and migrate along with the villus to the top [26]. As the intestine is the major site of the enzyme digestion and absorption of nutrients, the efficiency of absorption and hence feed conversion ratio largely depends on the morphology of intestine [27]. A deeper crypt may indicate faster tissue turnover to permit renewal of the villus, which suggests that the host's intestinal response mechanism is trying to compensate for normal sloughing or atrophy of villus due to inflammation from pathogens and their toxins [28]. Previous research has shown that the intestinal morphology, specifically structures such as villus, crypts and the thickness of mucosa, were altered by the composition of diet [29]. The increase in villus height and crypt depth is associated with healthy turnover of epithelial cell and active cell mitosis [30].

\section{CONCLUSION}

Hy-Line Brown laying hens fed high $\mathrm{AME}_{\mathrm{n}}$ diet (i.e., 3,050 $\mathrm{kcal} / \mathrm{kg}$ in the current experiment) tended to overconsume energy with a positive effect on feed intake, feed conversion ratio, nutrient digestibility, and intestinal morphology but not in egg production and egg mass.

\section{CONFLICT OF INTEREST}

We certify that there is no conflict of interest with any financial organization regarding the material discussed in the manuscript.

\section{ACKNOWLEDGMENTS}

This work supported by the "Cooperative Research Program for Agriculture Science \& Technology Development (Project title: The study of management and disease for animal welfare of laying hens, Project No.PJ010952)." Rural Development Administration, Republic of Korea and this study was supported by 2018 the RDA Fellowship Program of, Rural Development Administration, Republic of Korea.

\section{REFERENCES}

1. Grobas S, Mendez J, De Blas C, Mantoes GG. Influence of dietary energy, supplemental fat and linoleic acid concentration on performance of laying hens at two ages. Br Poult Sci 1999; 40:681-7.

2. Harms RH, Russell GB, Sloan DR. Performance of four strains of commercial layers with major changes in dietary energy. J Appl Poult Res 2000;9:535-41.

3. Wu G, Bryant MM, Voitle RA, Roland Sr. DA. Effect of dietary energy on performance and egg composition of Bovans white and Dekalb white hens during phase I. Poult Sci 2005;84:16105.

4. Wu G, Bryant MM, Gunawardana P, Roland Sr DA. Effect of nutrient density on performance, egg components, egg soilds, egg quality, and profits in eight commercial leghorn strain during phase I. Poult Sci 2007;86:691-7.

5. Grobas S, Mendez J, De Blas C, Mantoes GG. Laying hen productivity as affected by energy, supplemental fat, and linoleic acid concentration of the diet. Poult Sci 1999;78:1542-51.

6. Peguri A, Coon C. Effect of temperature and dietary energy on layer performance. Poult Sci 1991;70:126-38.

7. Junqueira OM, de Laurentiz AC, da Silva Filardi R, Rodrigues EA, Casartelli, EM. Effects of energy and protein levels on egg 
quality and performance of laying hens at early second production cycle. J Appl Poult Res 2006;15:110-5.

8. Committee on Nutrient Requirements of Poultry, National Research Council. Nutrient requirements of poultry. 9th ed. Washington, DC, USA: National Academy Press; 1994.

9. AOAC International. Official methods of analysis. 18th ed. Arlington, VA, USA: Association of Official Analytical Chemists; 2007.

10. Hayat Z, Cherian G, Pasha TN, Khattak FM, Jabber MA. Effect of feeding flax and two types of antioxidants on egg production, egg quality, and lipid composition eggs. J Appl Poult Res 2009;18:541-51.

11. Yannakopulos AL, Tserveni-Gousi AS. Quality characteristics of quail eggs. Br Poult Sci 1986;27:171-6.

12.Eisen EJ, Boheren BB, McKean HE. Haugh unit as a measure of egg albumen quality. Poult Sci 1962;41:1361-8.

13. Adeola O. Digestion and balance techniques in pigs. In: Lewis AJ, Southern LL, editors. Swine nutrition. Washington, DC, USA: CRC Press; 2001. pp. 903-16.

14. Swiatkiewicz S, Koreleski J. Effect of crude glycerine level in the diet of laying hens on egg performance and nutrient utilization. Poult Sci 2009;88:615-9

15. Kim JH, Seo SW, Kim CH, et al. Effect of dietary supplementation of crude glycerol or tallow on intestinal transit time and utilization of energy and nutrients in diets fed to broiler chickens. Livest Sci 2013;154:165-8.

16. Giannenas I, Taslie E, Chronis E, et al. Consumption of Agaricus bispours mushroom affects the performance, intestinal microbiota compostion and morphology, and antioxidant status of turkey poults. Anim Feed Sci Technol 2011;165:218-29.

17.SAS, SAS user's guide: Statistics, 9.2 ed. Cary, NC, USA: SAS Inst. Inc.; 2003.

18. Hill FW, Anderson DL, Dansky LM. Studies of the energy requirements of chickens. 3 . The effect of dietary energy level on the rate and gross efficiency of egg production. Poult Sci 1956;35:54-9.

19. Bouvarel I, Nys Y, Panheleux M, Lescoat P. How hens feed influences egg quality. INRA Prod Anim 2010;23:167-82.

20. Grobas S, Mendez J, Lazaro R, De Blas C, Mantoes GG. Influence of source and percentage of fat added to diet on performance and fatty acid composition of egg yolks of two strains of laying hens. Poult Sci 2001;80:1171-9.

21. Masoudi A, Chagi M, Bojaropour M, Mirzadeh K. Effects of different levels of date pits on performance, carcass characteristics and blood parameters of broiler chickens. J Appl Anim Res 2011;39:399-405.

22. Johnson TS, Zuk M. Parasites, morphology, and blood characters in male red jungle fowl during development. Condor 1998; 100:749-52.

23. Lucas AM, Jamroz C. Atlas of avian hematology. USDA Monograph 25. Washongton DC, USA: USDA; 1961.

24. Mateos GG, Sell JL, Eastwood JA. Rate of food passage (transit time) as influenced by level of supplemental fat. Poult Sci 1982; 61:94-100.

25.Sharifi SD, Afzalzadeh A, Bitaraf F, Hashemi M. Effects of blending and inclusion level of soy oil and its acidulated soapstock on broiler performance. 2010;52:147-51.

26.Schat K, Myers TJ. Avian intestinal immunity. Crit Rev Poult Biol 1991;3:19-34.

27. Soltan MA. Influence of dietary glutamine supplementation on growth performance, small intestinal morphology, immune response and some blood parameters of broiler chickens. Int J Poult Sci 2009;8:60-8.

28. Gao J, Zhang HJ, Yu SH, et al. Effects of yeast culture in broiler diet on performance and immunomodulatory functions. Poult Sci 2008;87:1377-84.

29. Nein S, Renema RA, Zuidhof MJ, Korver DR. Effect of metabolic efficiency and intestinal morphology on variability in n-3 polyunsaturated fatty acid enrichment of eggs. Poult Sci 2012;91:888-98.

30. Fan YK, Croom J, Christensen VL, et al. Jejunal glucose uptake and oxygen consumption in turkey poults selected for rapid growth. Poult Sci 1997;76:1738-45. 